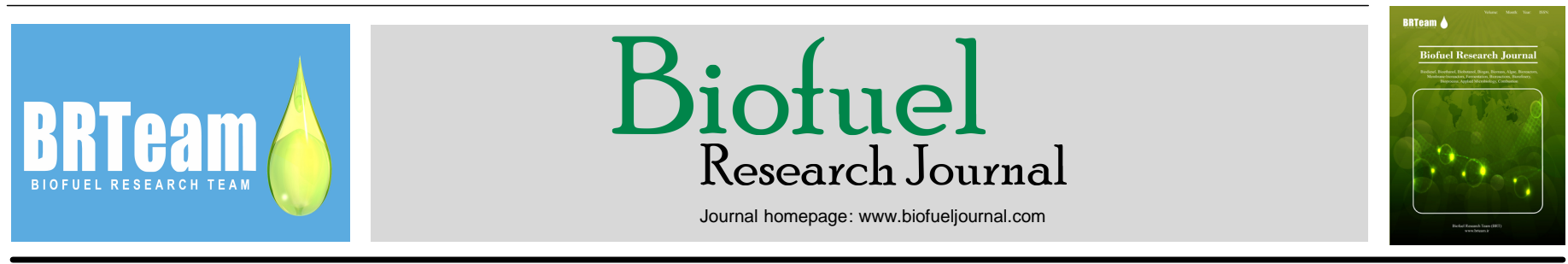

Review Paper

\title{
Recent updates on lignocellulosic biomass derived ethanol - A review
}

\author{
Rajeev Kumar $^{1}, *$, Meisam Tabatabaei ${ }^{2,3}$, Keikhosro Karimi ${ }^{4,5}$, Ilona Sárvári Horváth ${ }^{6}$ \\ ${ }^{1}$ Center for Environmental Research and Technology (CE-CERT), Bourns College of Engineering, University of California, Riverside, California, USA. \\ ${ }^{2}$ Microbial Biotechnology Department, Agricultural Biotechnology Research Institute of Iran (ABRII), AREEO, Karaj, Iran. \\ ${ }^{3}$ Biofuel Research Team (BRTeam), Karaj, Iran. \\ ${ }^{4}$ Department of Chemical Engineering, Isfahan University of Technology, Isfahan 84156-83111, Iran. \\ ${ }^{5}$ Microbial Industrial Biotechnology Group, Institute of Biotechnology and Bioengineering, Isfahan University of Technology, Isfahan 84156-83111, Iran. \\ ${ }^{6}$ Swedish Centre for Resource Recovery, University of Borås, 50190 Borås, Sweden.
}

\section{HIGHLIGHTS}

$>$ Cellulosic biomass is the only source for sustainable fuels.

$>$ Ethanol is a promising fuel candidate for near/long term applications.

$>$ Ethanol can also serve as a precursor for other fuels and chemicals.

$>$ However, processing cost for $2 \mathrm{G}$ ethanol is still high.

$>$ Thus, urgent research efforts are needed to bring the cost down.

\section{GRAPHICAL ABSTRACT}

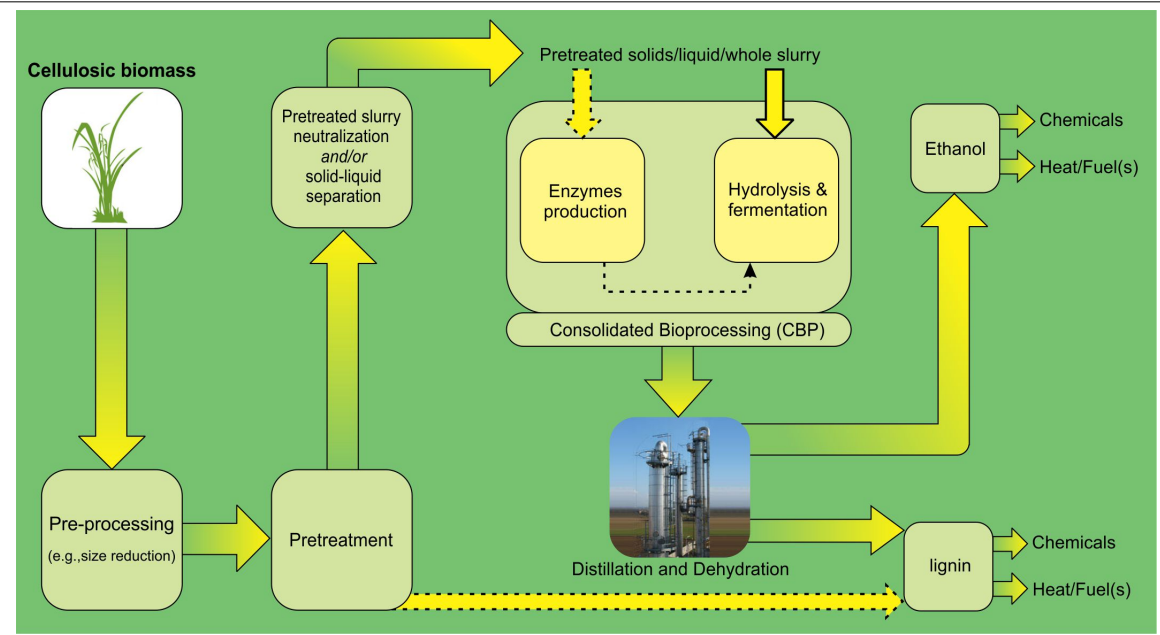

\section{ARTICLE INFO}

\section{Article history:}

Received 12 December 2015

Received in revised form 11 January 2016

Accepted 12 January 2016

Available online 1 March 2016

\section{Keywords:}

Pretreatment

Cellulase

Fermentation

Consolidated bioprocessing

\begin{abstract}
Lignocellulosic (or cellulosic) biomass derived ethanol is the most promising near/long term fuel candidate. In addition, cellulosic biomass derived ethanol may serve a precursor to other fuels and chemicals that are currently derived from unsustainable sources and/or are proposed to be derived from cellulosic biomass. However, the processing cost for second generation ethanol is still high to make the process commercially profitable and replicable. In this review, recent trends in cellulosic biomass ethanol derived via biochemical route are reviewed with main focus on current research efforts that are being undertaken to realize high product yields/titers and bring the overall cost down.
\end{abstract}

* Corresponding author at: Tel.: +1-951-781-5668

E-mail address: rkumar@cert.ucr.edu ; rajeev.dartmouth@gmail.com

Please cite this article as: Kumar R., Tabatabaei M., Karimi K., Sárvári Horváth I. Recent updates on lignocellulosic biomass derived ethanol - A review.

Biofuel Research Journal 9 (2016) 347-356. DOI: 10.18331/BRJ2016.3.1.4 


\section{Contents}

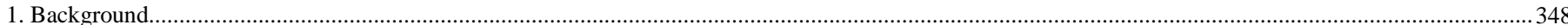

2. Why ethanol?

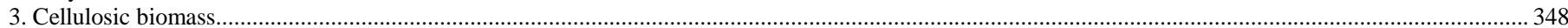

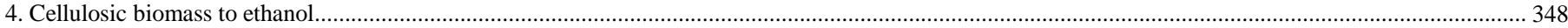

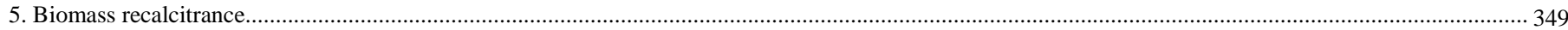

6. Pretreatment

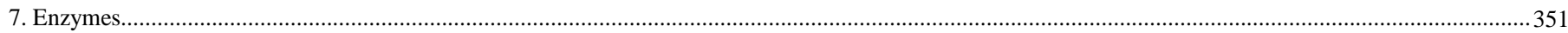

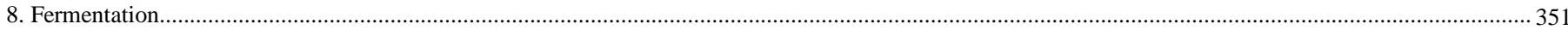

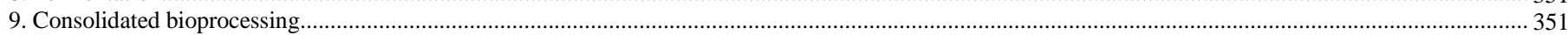

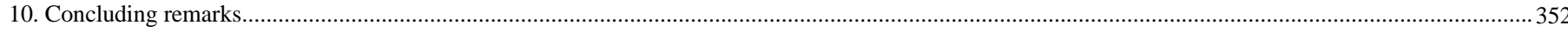

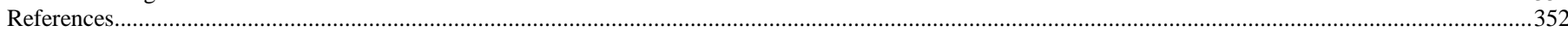

\section{Background}

Lignocellulosic biomass, otherwise termed as cellulosic biomass, is the only sustainable feedstock for biorefineries to meet the ever increasing energy demand (Wyman, 2007; Lynd et al., 2008). Cellulosic biomass conversion into biofuels and chemicals has several advantages including greenhouse gas mitigation, near carbon neutrality, lesser dependence on fossil fuels, and improvement in nations' energy security (Wyman, 2007). Lignocellulosic biomass derived ethanol is often termed as "second generation" or " $2 \mathrm{G}$ " as the "first generation" or " $1 \mathrm{G}$ " ethanol is derived from sugar cane, corn, wheat, and other starchy feedstocks (Jordan et al., 2012). Studies suggest that the net energy return on $2 \mathrm{G}$ ethanol is much higher than ethanol derived from corn (Lynd et al., 2006; Schmer et al., 2008). In addition, 2G ethanol has much higher potential for greenhouse gas (GHG) emissions reduction than $1 \mathrm{G}$ ethanol (Hsu et al., 2010). The cost of energy in lignocellulosic biomass at $\$ 60 /$ ton is roughly the same as $\$ 20 /$ barrel oil; however, due to recalcitrant nature of cellulosic biomass (Lynd et al., 1999), the current processing cost of $2 \mathrm{G}$ ethanol is still high and is much higher than $1 \mathrm{G}$ ethanol (www.doe.gov). The reasons for high processing costs of cellulosic biomass to biofuels are several including inherent recalcitrant nature of cellulosic biomass than corn, energy and chemical intensive pretreatment, inefficient and expensive enzymes resulting in low conversion at high solids loadings required for commercial application, incomplete conversion of all sugars to fuels and chemicals, and distillation (Lynd et al., 2008). This review discusses the recent research efforts made in biological conversion of cellulosic biomass to ethanol and challenges that need to be addressed to bring the processing cost further down.

\section{Why ethanol?}

Among renewable fuels, ethanol due to its long history, use, and inherent characteristics, such as low toxicity to microbes and environment, low boiling point, high octane number, and comparable energy content, is considered to be a primary fuel candidate for near/long term applications (Lynd et al., 1991; Lynd et al., 2008). Although ethanol's energy content is roughly $2 / 3^{\text {rd }}$ of gasoline and butanol, it has higher research octane number (RON; 107) than butanol (96) and gasoline (91-99) (Lynd, 1996). Research shows that ethanol can be used up to $85 \%(\mathrm{v} / \mathrm{v})$ in vehicles without major modifications (Balat et al., 2008). Although, novel biochemical, thermo-catalytic, and hybrid routes are being developed to produce drop-in fuels and fuel additives to meet the infrastructure and other requirements (Huber et al., 2006; Anbarasan et al., 2012; Buijs et al., 2013; Caratzoulas et al., 2014; Harvey and Meylemans, 2014; Sreekumar et al., 2014). Figure 1 shows that ethanol derived from cellulosic biomass can also be used to produce other fuel candidates such as butanol, gasoline, hydrogen, diesel, and others (Whitcraft et al., 1983; Costa et al., 1985; Deluga et al., 2004; Narula et al., 2015; Riittonen et al., 2015). Moreover, ethanol can also serve as a precursor for several other chemicals and intermediates that are currently derived from non-renewable resources (Angelici et al., 2013; Sun and Wang, 2014).

\section{Cellulosic biomass}

Lignocellulosic biomass includes forestry residues (e.g., hard \& softwood),

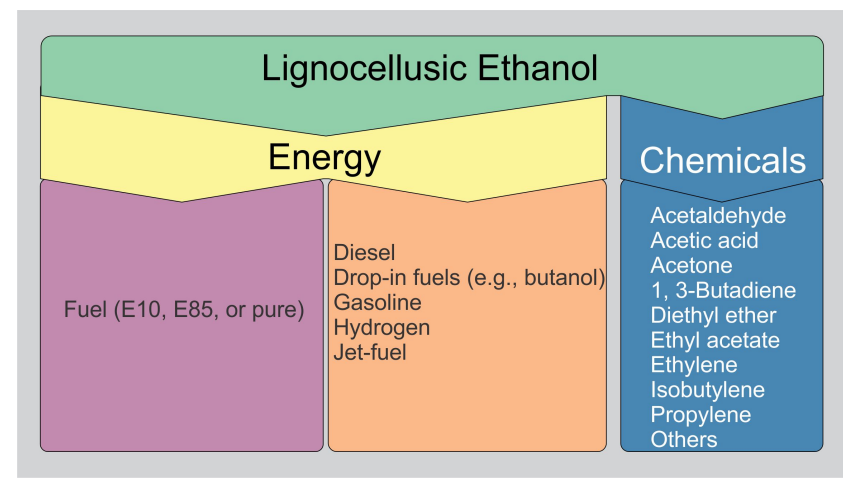

Fig.1. Promising applications of lignocellulosic ethanol for sustainable energy and chemicals.

agricultural residues (e.g., corn stover, wheat straw, rice straw), herbaceous (e.g., switchgrass, miscanthus), and plants that grow in arid regions (e.g., Agave) (Somerville et al., 2010). The 2011 report from the United States (US) Department of Energy (DOE) suggests that in the US alone more than a billion ton of lignocellulosic biomass is potentially available at $\sim \$ 60 /$ ton for conversion into $>20$ billion gallons of cellulosic biofuels (Perlack and Stokes, 2011). Whereas, a study published by Lal in 2005 estimated that total crop residue available is more than one billion ton in the US alone and more than 9 billion ton world-wide (Lal, 2005) Lignocellulosic biomass is primarily composed of cellulose (35-50 wt. \%, dry basis), hemicelluloses (15-30\%), pectin (2-5\%), and lignin (12-35\%) Cellulose and hemicelluloses that make more than $50 \%$ of total mass can be potentially converted to sugars for their conversion to ethanol. Lignin can be burned to meet the plants energy requirement and/or valorized to make fuels and chemicals (Ragauskas et al., 2014; Wyman and Ragauskas, 2015).

\section{Cellulosic biomass to ethanol}

Figure 2 shows the simple process flow diagram of converting cellulosic biomass to ethanol that is comprised of several steps: 1) biomass size reduction, 2) pretreatment, 3) enzymes production, 4) enzymatic hydrolysis of pretreated solids to fermentable sugars, 5) fermentation of sugars to ethanol, and 6) ethanol recovery. Steps 4 and 5 have several process configurations including separate hydrolysis and fermentation (SHF), simultaneous saccharification and fermentation (SSF), simultaneous saccharification and co-fermentation (SSCF) of hexose and pentose sugars, and consolidated bioprocessing (CBP), that combines enzymes production, enzymatic saccharification, and fermentation in a single step. Most pretreatments require some sort of size reduction to achieve better efficiency in terms of sugar release in pretreatment and/or biological conversion (Zhu and Pan, 2010). Nonetheless, pretreatment and enzymes are the most expensive 


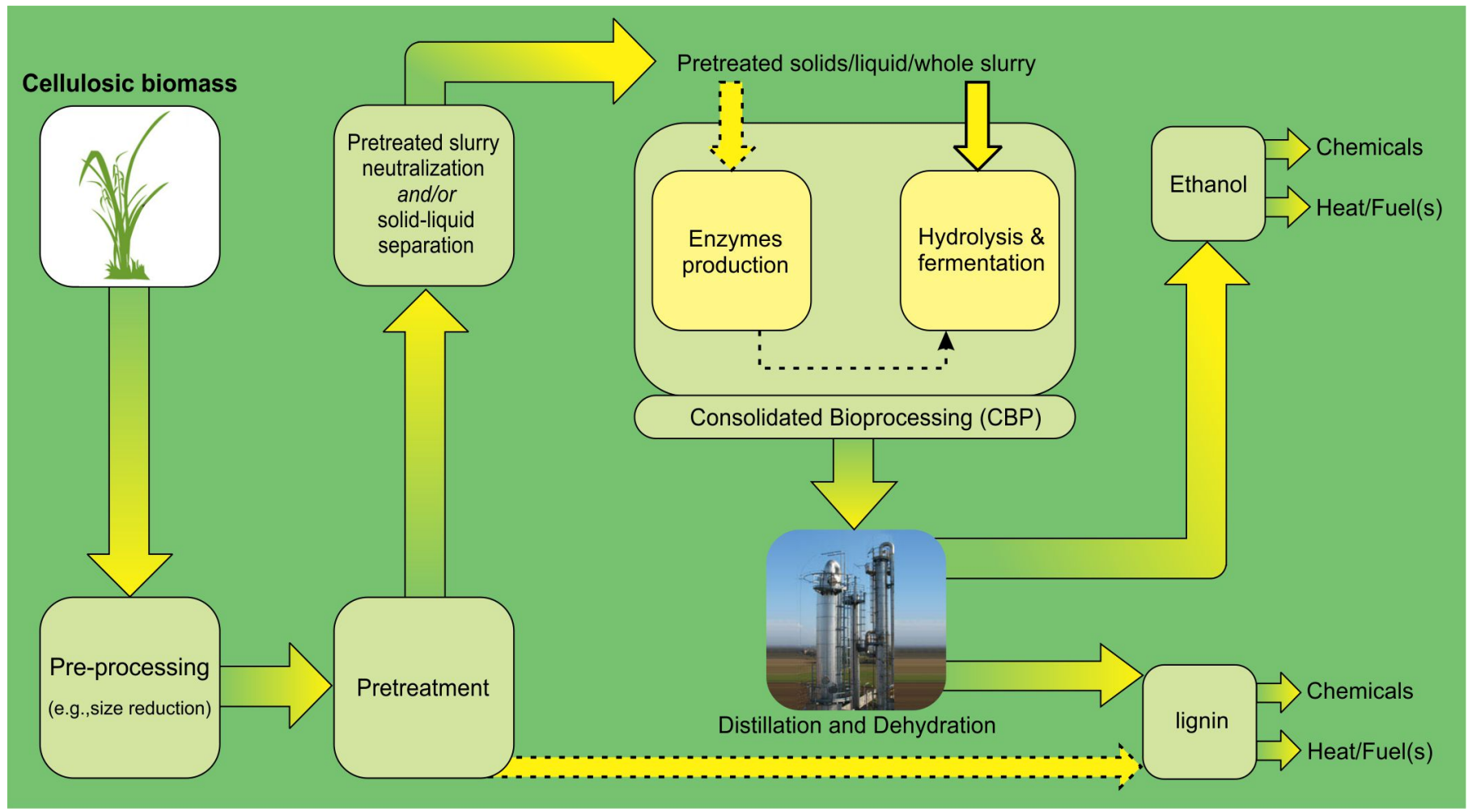

Fig.2. Schematic of second generation ethanol production process.

contributing factors to the $2 \mathrm{G}$ ethanol processing cost (Lynd et al., 2008), and, thus, have drawn a lot of attention in recent years.

\section{Biomass recalcitrance}

The inherent resistance of cellulosic biomass to pathogens, enzymes/microbes, and/or chemicals is called recalcitrance (Lynd et al., 1999), and is perceived to be majorly contributed by lignin including its amount, location, and type (syringyl vs. guacyl) (Studer et al., 2011; Ding et al., 2012). Other components such as pectin, hemicellulose, cellulose characteristics, and other biomass features are also believed to contribute to the plant's recalcitrance (Mohnen, 2008; Kumar et al., 2009b; Foston et al., 2011; Urbanowicz et al., 2012, Kumar and Wyman, 2013). However, it appears that all these features directly and/or indirectly contribute to the enzymes accessibility to plant's carbohydrates and/or enzymes effectiveness (Kumar and Wyman, 2010). Accessibility can further be divided into macro and micro-accessibility in that lignin, hemicellulose, and other components removal/relocation enhances macro-accessibility; whereas, changes in cellulose characteristics such as crystallinity and/or change in allomorph type (e.g., cellulose I to cellulose II and III) enhance micro-accessibility (Kumar and Wyman, 2013). However, for high sugar yields at low enzyme loadings, it is vital to enhance both macro and micro-accessibility and increase enzymes effectiveness (Kumar and Wyman, 2013), as enzymes are prone to deactivation and inhibition by their own end products and other components (Mandels and Reese, 1965; Reese and Mandels, 1980; Holtzapple et al., 1990; Kumar and Wyman, 2009b; Andrić et al., 2010; Ximenes et al., 2010; Kumar and Wyman, 2014).

Plants are being engineered to make them less resistant to break down, consequently requiring less harsher pretreatments and low enzyme loadings for high product yields (Funaoka et al., 1995; Chen and Dixon, 2007; Grabber et al., 2008; Sticklen, 2008; Fu et al., 2011). Since lignin is believed to be one of major impediments in low cost conversion of lignocellulosic biomass, the focus of most plant engineering studies is to alter the content, location, and type of lignin (syringyl: guaiacyl or S:G ratio) (Ding et al., 2012; Ragauskas et al., 2014; Wilkerson et al., 2014; Wagner et al., 2015). In this direction, an investigation showed that down regulating the hydroxycinnamoyl transferase (HCT) and caffeic acid 3-O-methyltransferase (COMT) genes in alfalfa (one of the energy grasses) resulted in decreased lignin content and enhanced sugar release (Chen and Dixon, 2007). However, in contrast to other studies (Davison et al., 2006; Studer et al., 2011), the changes in $\mathrm{S}$ : G ratios for these transgenic lines had no correlation with sugar release. $\mathrm{Fu}$ and coworkers recently showed that down regulating COMT gene in switchgrass resulted in a decrease in lignin content, reduction in the $S: G$ lignin monomer ratio, improved forage quality, and an increase in the ethanol yield by up to $38 \%$ (Fu et al., 2011). On the other hand, changes in hemicelluloses, pectins, and other components in terms of backbone composition, chain length, branching, and content have also shown promise for reduction in plants recalcitrance (Daniel et al., 2006; Bindschedler et al., 2007; Dhugga, 2007; Mohnen, 2008; Foston et al., 2011; Cook et al., 2012; Urbanowicz et al., 2012; Doblin et al., 2014). However, more research efforts need to be directed to investigate the effect of hemicelluloses genetic engineering on plants recalcitrance (Pauly et al., 2013). Nonetheless, with genetically engineered plants, the question of their performance in field trials in terms of their growth, resistance to pathogens, and sugars yields often arises as most plant engineering studies are performed on model plants, such as Arabidopsis thaliana, grown in greenhouses. However, a recent study by researchers at the BioEnergy Science Center (BESC), one of the bioenergy research centers funded by the United States Department of Energy, showed that the field trials of switchgrass transgenic lines resulted in similar sugar and ethanol yields to those grown in greenhouses. In addition, the switchgrass grown in the fields was not susceptible to rust (Baxter et al., 2014).

\section{Pretreatment}

Pretreatment is a processing step to make lignocellulosic biomass more amenable to biological conversion at high yields that otherwise suffers from low yields and high processing costs (Wyman et al., 2013). The details on the type of earlier pretreatment technologies including liquid hot water or hydrothermal (Bobleter et al., 1976), dilute acid (Grethlein 
and Converse, 1991; Yang and Wyman, 2009; Trajano and Wyman, 2013), (non) aqueous and (near) critical ammonia (Dale and Moreira, 1982; Chundawat et al., 2013), ammonia recycled percolation (ARP), and soaking in aqueous ammonia (SAA) (Yoon et al., 1995; Kim et al., 2003), lime (Chang et al., 1997; Vincent et al., 1998), and others and their impact on biomass features and biological digestibility, and their economic viability are available in several previous and recent reviews (Millett et al., 1975; Lin et al., 1981; Ladisch et al., 1983; Knauf and Moniruzzaman, 2004; Mosier et al., 2005; Yang and Wyman, 2008; da Costa Sousa et al., 2009; Kumar et al., 2009a ; Karimi et al., 2013). It is worth mentioning a few new promising pretreatments that have recently been developed including co-solvent enhanced lignocellulosic fractionation (CELF) (Nguyen et al., 2015a; Nguyen et al., 2015b), co-solvent based lignocellulosic fractionation (COSLIF) (Zhang et al., 2007), extractive ammonia (EA) pretreatment (Chundawat et al., 2013), $\gamma$-valerolactone (GVL) pretreatment (Shuai et al., 2016; Wu et al., 2016), pretreatment applying ionic liquid(s) (Swatloski et al., 2002; Dadi et al., 2006; Seema et al., 2009; Li et al., 2010; Cheng et al., 2011; PerezPimienta et al., 2013; Singh and Simmons, 2013; Konda et al., 2014), sulfite pretreatment to overcome recalcitrance of lignocellulose (SPORL) (Zhu et al., 2009), and switchable butadiene sulfone pretreatment (de Frias and Feng, 2013).

Nonetheless, an ideal pretreatment should be feedstock agnostic, should be less energy and chemical intensive, and should generate highly reactive solids by enhancing their both macro and micro-accessibility (Kumar and Wyman, 2013) for their high yield conversion at low enzyme (biocatalyst) loadings with minimal sugars degradation (Yang and Wyman, 2008) and water demand (Kumar and Murthy, 2011). Although, as shown in Figure 3, some of the previously (and newly) developed pretreatment technologies meet some of these criteria (Dale and Ong, 2012), a rigorous techno-economic and life cycle analyses are necessary to show their viability for commercial applications (Mosier et al., 2005). For example, COSLIF pretreatment fractionates biomass at low temperatures $\left(\sim 50^{\circ} \mathrm{C}\right)$ and has been shown to be highly effective for variety of biomass types in terms of high sugar (especially, glucan to glucose) yields at low enzyme loadings (as low as 1 filter paper unit (FPU)/g glucan, i.e., $\sim 2 \mathrm{mg}$ of protein) (Rollin et al., 2011; Zhang et al., 2007 ). However, COSLIF requires concentrated phosphoric acid (>80 wt.\%), which poses a recovery and recycling challenge, and doesn't appear to be highly effective for softwoods (Zhang et al., 2007). Pretreatments applying ionic liquids also appear highly promising and feedstock agnostic; however, the current cost of ionic liquids $(>\$ 3$ per $\mathrm{kg}$ ) makes this approach less commercially attractive (Klein-Marcuschamer et al., 2011). However, research efforts are underway at the Joint BioEnergy Institute, USA to develop ionic liquids from cellulosic biomass components (termed as bionic liquid) to drive the cost down (Socha et al., 2014). On the other hand, recently developed CELF uses a low boiling and renewable tetrahydrofuran (THF) as a cosolvent (boiling point $-66^{\circ} \mathrm{C}$ ), and fractionates all biomass types into three pure streams: highly reactive glucan enriched solids, xylose and other hemicellulose components in the liquid stream at near theoretical yields, and an ultra-pure stream of lignin, with $>80 \%$ original lignin removed and recovered (Cai et al., 2013; Cai et al., 2014; Nguyen et al., 2015a). In addition, unlike most other pretreatment/fractionation technologies, CELF can be tuned to produce fuel precursors furfural, hydroxymethylfurfural, and levulinic acid at high yields for their catalytic conversion to drop-in fuels (Cai et al., 2013; Cai et al., 2014). CELF as a pretreatment defeats biomass recalcitrance and achieves high ethanol yields and titers at enzyme loadings as low as $2 \mathrm{mg}$ protein/g glucan (Nguyen et al., 2015a; Nguyen et al., 2015b); however, recovery and recycling of THF is the key to the commercial scalability and feasibility of the technology.

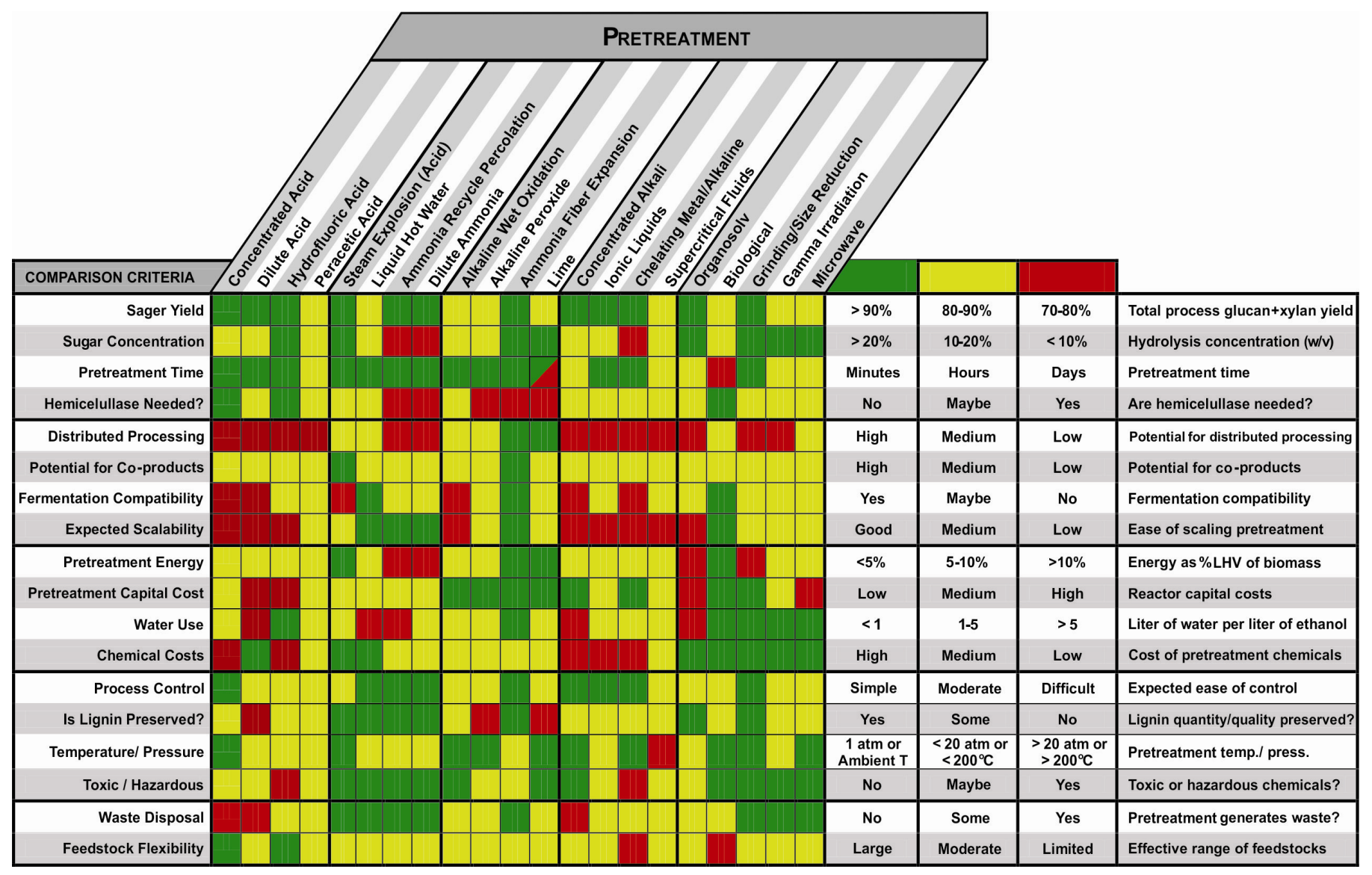

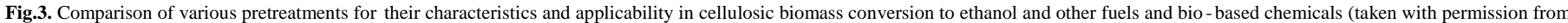
Dale and Ong (2012)). 


\section{Enzymes}

High cost of cellulase and other accessory enzymes required for biological conversion of pretreated lignocellulosic biomass into sugars is another major impediment in the commercialization of lignocellulosic biomass to fuels and chemicals (Culbertson et al., 2013; Hong et al., 2013). Although enhancement in enzymes stability, activity, and several fold decrease in cost have been reported in recent years, enzymes available at about $\$ 1.5-\$ 2.0$ per $\mathrm{kg}$ are still expensive (Stephen et al., 2012). Nonetheless, the enzymes cost per gallon would vary with the pretreatment applied, the extent of anhydrous polymers (cellulose and hemicellulose) conversion to sugars, and sugars conversion to ethanol (Klein-Marcuschamer et al., 2012).

In addition to enzymes low accessibility to (hemi) cellulose, their strong inhibition by components generated during pretreatment (e.g., phenols) (Ximenes et al., 2010; Kim et al., 2011) and enzymatic saccharification (Mandels and Reese, 1965; Halliwell and Griffin, 1973; Kumar and Wyman, 2008; Kumar and Wyman, 2009b; Qing et al., 2010; Kumar and Wyman, 2014) is one of the main reasons for high loading of enzymes required for commercially viable sugar yields. In addition, enzymes unproductive binding to lignin (Yang and Wyman, 2006; Selig et al., 2007; Kumar and Wyman, 2009a; Kumar and Wyman, 2009c; Kumar et al., 2012; Li et al., 2013) and pseudo-lignin (Hu et al., 2012; Kumar et al., 2013) also lowers the amount of enzymes available and affects their effectiveness. The rates and yields are also substantially lower at industrially relevant high solids loading than with low solids loadings (Kristensen et al., 2009; Di Risio et al., 2011) often applied and studied in laboratory settings. Although cellulase end-product inhibition by glucose can be alleviated in a process configuration called simultaneous saccharification and fermentation (SSF), and inhibition by cellobiose and hemicellulose oligomers can be alleviated by supplementing cellulase with accessory enzymes, low reaction rates at fermentation temperatures $\left(32-37^{\circ} \mathrm{C}\right)$ (Alfani et al., 2000; Elia et al., 2008) and inhibition by ethanol still pose a challenge to high yields and titers at low enzyme loadings (Podkaminer et al., 2011; Podkaminer et al., 2012).

The discovery of novel non-hydrolytic enzymes like polysaccharide monooxygenases (LPMOs), appears to be highly promising in reducing cellulase and ultimately overall processing costs (Vaaje-Kolstad et al., 2010; Horn et al., 2012; Agger et al., 2014). Although the mechanism is not clear yet, these LPMOs are believed to oxidize the highly recalcitrant crystalline regions of cellulose and create more reducing/non-reducing ends for cellulase components to attack (Horn et al., 2012). In fact, a recent study with current generation of cellulase enzymes containing LPMOs (e.g., Cellic ${ }^{\circledR}$ Ctec2 from Novozymes) showed that it is possible to achieve higher rates and yields in SHF than SSF (Cannella and Jørgensen, 2014), which with older generation of enzymes was the other way around (Alfani et al., 2000; Lynd et al., 2002). This may be due to the fact that LPMOs require an electron donor, e.g., oxygen, for their effective action (Hu et al., 2014; Müller et al., 2015). Nonetheless, in addition to loss of some of the carbohydrates and requirement of different process configurations, the aldonic acids resulting from polysaccharides oxidation by LPMOs can be inhibitory to enzymes as well microbes (Cannella et al., 2012). In addition, it was recently shown that LPMOs can make cellulase cocktails less stable (Scott et al., 2015). Thus, it is still to be seen whether these new non-hydrolytic enzymes would be advantageous in the long run.

\section{Fermentation}

Incomplete utilization of all the sugars including hexoses (C6; glucose, galactose, and mannose) and pentoses (C5 sugars; xylose and arabinose) is another factor for high cost of $2 \mathrm{G}$ ethanol. In recent years, however, a lot more progress has been made in modifying various microbes including yeast (e.g., Saccharomyces cerevisiae, Scheffersomyces (Pichia) stipites, Kluyveromyces marxianus) and bacteria (e.g., Zymomonas mobilis, Escherichia coli, Klebsiella oxytoca) to make them capable of fermenting both hexoses and pentoses at comparatively high yields (metabolic ( $\mathrm{g}$ ethanol/g sugar consumed) as well productive yield (g ethanol/g of total potential) (Hahn-Hagerdal et al., 1986; Jeffries and Jin, 2004; Jeffries, 2005; Kuhad et al., 2011; Fox et al., 2012; Laluce et al., 2012; Kim et al., 2013; Wang et al., 2013). The exhaustive details on the research efforts in making microbes capable of fermenting pentoses can be found in several recent reviews (Kuhad et al., 2011; Kim et al., 2012; Laluce et al., 2012; Balan,
2014; He et al., 2014). It is worth noting that in addition to making (mesophilic/thermophilic) microbes capable of fermenting pentoses together with hexoses, research efforts are also underway to make microbes metabolize cellobiose and higher cellodextrins directly to ethanol and other valuable metabolites. Although the concept is not new, as it was shown by (Spindler et al., 1989) that by directly fermenting cellobiose, it is possible to achieve higher conversion and ethanol yields, Galazka et al. (2010) recently reported a much higher conversion and yields by reconstituting the Neurospora crassa cellodextrins transporters system into S.cerevisiae. In another study, Ha et al. (2010) engineered a yeast strain to co-ferment cellobiose, glucose, and xylose together however, high glucose concentrations expected after enzymatic saccharification of pretreated solids at high solids loading suppressed the metabolism of xylose. Although some of the engineered strains show great promises in metabolizing both hexose as well as pentose sugars, the incomplete pentose sugars utilization, low metabolic and productive yields and rates, low ethanol titers ( $<5 \mathrm{wt} \%$ ethanol) than yeasts $>10 \mathrm{wt} \%$, and inhibition by process-generated inhibitors (e.g., acetic acid , furfural) are still some of the challenges that must be overcome.

\section{Consolidated bioprocessing}

As shown in Figure 4, three main steps in lignocellulosic biomass conversion- enzymes production, biological hydrolysis of biomass to sugars and oligomers, and fermentative metabolites (e.g., ethanol) production- can be combined into a single bioprocessing system "Direct Microbial Conversion (DMC)" (Viljoen et al., 1926; Cooney et al., 1979; Demain et al., 2005) or lately known as "Consolidated Bioprocessing (CBP)" (Lynd, 1996). Studies have shown that CBP system combining three processing steps into one can save capital as well as operating costs (Lynd et al., 2008).

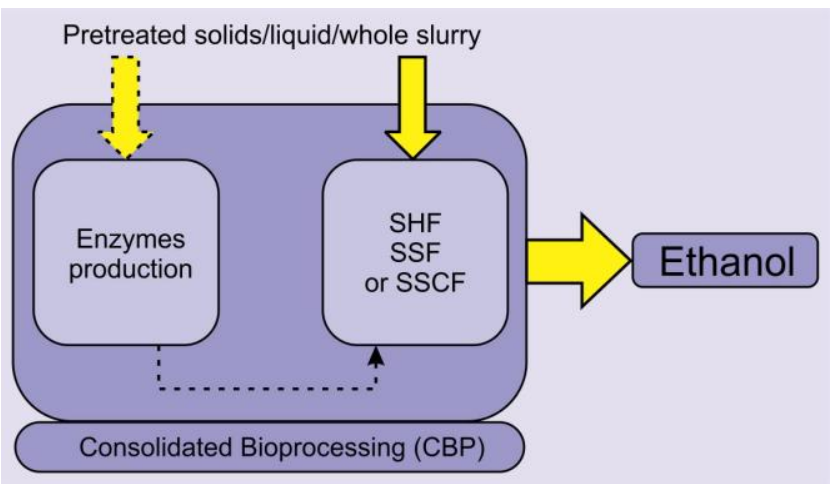

Fig.4. A simplified schematic of consolidated bioprocessing (CBP) system integrating three steps in lignocellulosic biomass conversion: enzymes production, hydrolysis (saccharification) of glucan and hemicelluloses in pretreated solids, and fermentation of sugars to ethanol (adapted from Lynd et al. (2002)). SHF, separate hydrolysis and fermentation; SSF, simultaneous saccharification and fermentation; and SSCF, simultaneous saccharification and co-fermentation.

There are several cellulolytic/non- cellulolytic and thermophilic/mesophilic candidate microorganisms for CBP including bacteria, e.g., Clostridium thermocellum (Lynd et al., 1989; Argyros et al., 2011; Shao et al., 2011), Thermoanaerobacterium saccharolyticum (Shaw et al., 2008), Clostridium phytofermentans (Jin et al., 2012), Caldicellulosiruptor bescii (Yang et al., 2009; Chung et al., 2014), and yeasts, e.g., S. cerevisiae and thermotolerant $K$. marxianus (Yamada et al., 2013). Thermophiles have an added advantage of higher hydrolysis rates and less probability of contaminations at fermentation temperatures of $>60^{\circ} \mathrm{C}$ than mesophiles that usually operate at temperatures $<50^{\circ} \mathrm{C}(\mathrm{Olson}$ et al., 2012). However, most CBP organisms identified and developed, wild or genetically engineered, to date suffer from either low ethanol titer $(<3 \mathrm{wt} \%)$, low growth, or low metabolic yield and/or productive yield 
Among thermophiles, $C$. thermocellum- an anaerobe- is the most promising candidate due to its much faster degradation rates of crystalline cellulose than possible with free fungal enzymes (Shao et al., 2011), but it lacks the ability to metabolize pentoses. Another problem with $C$. thermocellum is its low metabolic yield $(<0.30 \mathrm{~g}$ ethanol/ $\mathrm{g}$ sugar)- due to waste of carbon to undetectable and undesired products (Argyros et al., 2011; Deng et al., 2013; Yee et al., 2014)- and low ethanol tolerance $(<30 \mathrm{~g} / \mathrm{L})($ Deng et al., 2013). A recent report, however, has shown that a titter of $38 \mathrm{~g} / \mathrm{L}$ ethanol can be produced with $C$. thermocellum in a co-culture with $T$. saccharolyticum (Argyros et al., 2011). T. saccharolyticum- a thermophilic anaerobe- has been engineered to produce a high titer of ethanol (33-37 g/L) (Shaw et al., 2008), but it lacks the ability to hydrolyze cellulose and needs exogenous supplementation of cellulase.

C. bescii has recently been engineered to produce ethanol at high metabolic yield; however, the productive yields are too low for commercial application yet (Chung et al., 2014). It is important to note here that although all these microbes perform greatly with pure (hemi) cellulose compounds, their performance is comparatively not that great with real (unpretreated/pretreated) lignocellulosic biomass solids, most possibly due to inhibition of their free/cell-bound enzymes by lignin, hemicellulose, and/or other compounds in the unpretreated/pretreated solids (Shao et al., 2011; Brunecky et al., 2013; Resch et al., 2013). In addition to thermophilic and other bacteria, research is also underway in modifying yeasts to convert them into CBP organisms (Hasunuma and Kondo, 2012; Yamada et al., 2013). However, most of these genetically engineered strains still need some supplementation of exogenous enzymes for high ethanol yields

\section{Concluding remarks}

In summary, a lot of progress has been made in recent years in terms of engineering plants, to make them less recalcitrant to breakdown, engineering microorganisms, to enhance their metabolic/productive yields and products/inhibitors tolerance, and developing novel pretreatments and improved enzyme cocktails to make lignocellulosic biomass derived ethanol commercially viable and profitable. Although several cellulosic ethanol plants are up and in operation around the globe; however, continued research efforts are still needed to bring the cost further down to make cellulosic ethanol plants profitable and replicable.

\section{References}

[1] Agger, J.W., Isaksen, T., Várnai, A., Vidal-Melgosa, S., Willats, W.G.T., Ludwig, R., Horn, S.J., Eijsink, V.G.H., Westereng, B., 2014. Discovery of LPMO activity on hemicelluloses shows the importance of oxidative processes in plant cell wall degradation. Proc. Natl. Acad. Sci. 111(17), 6287-6292.

[2] Alfani, F., Gallifuoco, A., Saporosi, A., Spera, A., Cantarella, M., 2000. Comparison of SHF and SSF processes for the bioconversion of steamexploded wheat straw. J. Ind. Microbiol. Biotechnol. 25(4), 184-192.

[3] Anbarasan, P., Baer, Z.C., Sreekumar, S., Gross, E., Binder, J.B., Blanch, H.W., Clark, D.S., Toste, F.D., 2012. Integration of chemical catalysis with extractive fermentation to produce fuels. Nature. 491(7423), 235-239.

[4] Andrić, P., Meyer, A.S., Jensen, P.A., Dam-Johansen, K., 2010. Reactor design for minimizing product inhibition during enzymatic lignocellulose hydrolysis: I. Significance and mechanism of cellobiose and glucose inhibition on cellulolytic enzymes. Biotechnol. Adv. 28(3), 308-324.

[5] Angelici, C., Weckhuysen, B.M., Bruijnincx, P.C.A., 2013. Chemocatalytic Conversion of Ethanol into Butadiene and Other Bulk Chemicals. Chem. Sus. Chem. 6(9), 1595-1614.

[6] Argyros, D.A., Tripathi, S.A., Barrett, T.F., Rogers, S.R., Feinberg, L.F., Olson, D.G., Foden, J.M., Miller, B.B., Lynd, L.R., Hogsett, D.A., Caiazza, N.C., 2011. High Ethanol Titers from Cellulose using Metabolically Engineered Thermophilic, Anaerobic Microbes. Appl. Environ. Microbiol. 77(23), 8288-8294.

[7] Balan, V., 2014. Current Challenges in Commercially Producing Biofuels from Lignocellulosic Biomass. ISRN Biotechnol 2014

[8] Balat, M., Balat, H., Öz, C., 2008. Progress in bioethanol processing. Prog. Energy Combust. Sci. 34(5), 551-573.
[9] Baxter, H.L., Mazarei, M., Labbe, N., Kline, L.M., Cheng, Q. Windham, M.T., Mann, D.G.J., Fu, C., Ziebell, A., Sykes, R.W., Rodriguez, M., Davis, M.F., Mielenz, J.R., Dixon, R.A., Wang, Z.Y., Stewart, C.N., 2014. Two-year field analysis of reduced recalcitrance transgenic switchgrass. Plant Biotechnol. J. 12(7), 914924.

[10] Bindschedler, L.V., Tuerck, J., Maunders, M., Ruel, K., Petit-Conil, M., Danoun, S., Boudet, A.M., Joseleau, J.P., Paul Bolwell, G., 2007. Modification of hemicellulose content by antisense downregulation of UDP-glucuronate decarboxylase in tobacco and its consequences for cellulose extractability. Phytochemistry. 68(21), 2635-2648.

[11] Bobleter, O., Niesner, R., Röhr, M., 1976. The hydrothermal degradation of cellulosic matter to sugars and their fermentative conversion to protein. J. Appl. Polym. Sci. 20(8), 2083-2093.

[12] Brunecky, R., Alahuhta, M., Xu, Q., Donohoe, B.S., Crowley, M.F. Kataeva, I.A., Yang, S.J., Resch, M.G., Adams, M.W.W., Lunin, V.V., Himmel, M.E., Bomble, Y.J., 2013. Revealing Nature's Cellulase Diversity: The Digestion Mechanism of Caldicellulosiruptor bescii CelA. Science. 342(6165), 1513-1516.

[13] Buijs, N.A., Siewers, V., Nielsen, J., 2013. Advanced biofuel production by the yeast Saccharomyces cerevisiae. Curr. Opin. Chem. Biol. 17(3), 480-488.

[14] Cai, C.M., Nagane, N., Kumar, R., Wyman, C.E., 2014. Coupling metal halides with a co-solvent to produce furfural and 5-HMF at high yields directly from lignocellulosic biomass as an integrated biofuels strategy. Green Chem. 16(8), 3819-3829.

[15] Cai, C.M., Zhang, T., Kumar, R., Wyman, C.E., 2013. THF cosolvent enhances hydrocarbon fuel precursor yields from lignocellulosic biomass. Green Chem. 15(11), 3140-3145.

[16] Cannella, D., Hsieh, C.W., Felby, C., Jorgensen, H., 2012 Production and effect of aldonic acids during enzymatic hydrolysis of lignocellulose at high dry matter content. Biotechnol. Biofuels. 5(1), 26.

[17] Cannella, D., Jørgensen, H., 2014. Do new cellulolytic enzyme preparations affect the industrial strategies for high solids lignocellulosic ethanol production? Biotechnol. Bioeng. 111(1), 5968

[18] Caratzoulas, S., Davis, M.E., Gorte, R.J., Gounder, R., Lobo, R.F., Nikolakis, V., Sandler, S.I., Snyder, M.A., Tsapatsis, M., Vlachos, D.G., 2014. Challenges of and Insights into Acid-Catalyzed Transformations of Sugars. J. Phys. Chem. C. 118(40), 22815 22833.

[19] Chang, V.S., Burr, B., Holtzapple, M.T., 1997. Lime pretreatment of switchgrass. In Biotechnology for Fuels and Chemicals. Humana Press. pp, 3-19.

[20] Chen, F., Dixon, R.A., 2007. Lignin modification improves fermentable sugar yields for biofuel production. Nat. Biotechnol. 25(7), 759-761.

[21] Cheng, G., Varanasi, P., Li, C., Liu, H., Melnichenko, Y.B., Simmons, B.A., Kent, M.S., Singh, S., 2011. Transition of Cellulose Crystalline Structure and Surface Morphology of Biomass as a Function of Ionic Liquid Pretreatment and Its Relation to Enzymatic Hydrolysis. Biomacromolecules. 12(4), 933-941.

[22] Chundawat, S.P.S., Bals, B., Campbell, T., Sousa, L., Gao, D., Jin, M., Eranki, P., Garlock, R., Teymouri, F., Balan, V., Dale, B.E., 2013. Primer on Ammonia Fiber Expansion Pretreatment, in Aqueous Pretreatment of Plant Biomass for Biological and Chemical Conversion to Fuels and Chemicals. John Wiley and Sons, Ltd, pp. 169-200.

[23] Chung, D., Cha, M., Guss, A.M., Westpheling, J., 2014. Direct conversion of plant biomass to ethanol by engineered Caldicellulosiruptor bescii. Proc. Nat1. Acad. Sci. 111(24), 8931 8936

[24] Cook, C.M., Daudi, A., Millar, D.J., Bindschedler, L.V., Khan, S., Bolwell, G.P., Devoto, A., 2012. Transcriptional changes related to secondary wall formation in xylem of transgenic lines of tobacco altered for lignin or xylan content which show improved saccharification. Phytochemistry. 74, 79-89. 
[25] Cooney, C.L., Wang, D.I.C., Wang, S.D., 1979. Simultaneous cellulose hydrolysis and ethanol production by a cellulolytic anaerobic bacterium. Biotechnol. Bioeng. Symp. 8, 103-114.

[26] Costa, E., Uguina, A., Aguado, J., Hernandez, P.J., 1985. Ethanol to gasoline process: effect of variables, mechanism, and kinetics. Ind. Eng. Chem. Process Des. Dev. 24(2), 239-244.

[27] Culbertson, A., Jin, M., da Costa Sousa, L., Dale, B.E., Balan, V., 2013. In-house cellulase production from AFEXTM pretreated corn stover using Trichoderma reesei RUT C-30. RSC Adv. 3(48), 25960-25969.

[28] da Costa Sousa, L., Chundawat, S.P.S., Balan, V., Dale, B.E., 2009. 'Cradle-to-grave' assessment of existing lignocellulose pretreatment technologies. Curr. Opin. Biotechnol. 20(3), 339-347.

[29] Dadi, A.P., Varanasi, S., Schall, C.A., 2006. Enhancement of cellulose saccharification kinetics using an ionic liquid pretreatment step. Biotechnol. Bioeng. 95(5), 904-910.

[30] Dale, B.E., Moreira, M.J., 1982. A freeze-explosion technique for increasing cellulose hydrolysis. Biotechnol. Bioeng. Symp. 12, 31-44.

[31] Dale, B.E., Ong, R.G., 2012. Energy, wealth, and human development: Why and how biomass pretreatment research must improve. Biotechnol. Prog. 28(4), 893-898

[32] Daniel, G., Filonova, L., Kallas, A.M., Teeri, T.T., 2006. Morphological and chemical characterisation of the G-layer in tension wood fibres of Populus tremula and Betula verrucosa: labeling with cellulose-binding module CBM1HjCel7A and fluorescence and FE-SEM microscopy. Holzforschung. 60(6), 618-624.

[33] Davison, B.H., Drescher, S.R., Tuskan, G.A., Davis, M.F., Nghiem, N.P., 2006. Variation of S/G ratio and lignin content in a Populus family influences the release of xylose by dilute acid hydrolysis. Appl. Biochem. Biotechnol. 130, 427-435.

[34] de Frias, J.A., Feng, H., 2013. Switchable butadiene sulfone pretreatment of Miscanthus in the presence of water. Green Chem. 15(4), 1067-1078.

[35] Deluga, G.A., Salge, J.R., Schmidt, L.D., Verykios, X.E., 2004. Renewable Hydrogen from Ethanol by Autothermal Reforming. Science. 303(5660), 993-997.

[36] Demain, A.L., Newcomb, M., Wu, J.H.D., 2005. Cellulase, Clostridia, and Ethanol. Microbiol. Mol. Biol. Rev. 69(1), 124-154.

[37] Deng, Y., Olson, D.G., Zhou, J., Herring, C.D., Joe Shaw, A., Lynd, L.R., 2013. Redirecting carbon flux through exogenous pyruvate kinase to achieve high ethanol yields in Clostridium thermocellum. Metab. Eng. 15, 151-158.

[38] Dhugga, K.S., 2007. Maize Biomass Yield and Composition for Biofuels. Crop Sci. 47(6), 2211-2227.

[39] Di Risio, S., Hu, C.S., Saville, B.A., Liao, D., Lortie, J., 2011. Largescale, high-solids enzymatic hydrolysis of steam-exploded poplar. Biofuels Bioprod. Biorefin. 5(6), 609-620.

[40] Ding, S.Y., Liu, Y.S., Zeng, Y., Himmel, M.E., Baker, J.O., Bayer, E.A., 2012. How Does Plant Cell Wall Nanoscale Architecture Correlate with Enzymatic Digestibility? Science. 338(6110), 1055-1060.

[41] Doblin, M.S., Johnson, K.L., Humphries, J., Newbigin, E.J., Bacic, A., 2014. Are designer plant cell walls a realistic aspiration or will the plasticity of the plant's metabolism win out? Curr. Opin. Biotechnol. 26, $108-114$.

[42] Elia, T.P., Jose, M.O., Mercedes, B., Lisbeth, O., 2008. Comparison of SHF and SSF processes from steam-exploded wheat straw for ethanol production by xylose-fermenting and robust glucose-fermenting Saccharomyces cerevisiae strains. Biotechnol. Bioeng. 100(6), 11221131.

[43] Foston, M., Hubbell, C.A., Samuel, R., Jung, S., Fan, H., Ding, S.Y., Zeng, Y., Jawdy, S., Davis, M., Sykes, R., Gjersing, E., Tuskan, G.A., Kalluri, U., Ragauskas, A.J., 2011. Chemical, ultrastructural and supramolecular analysis of tension wood in Populus tremula $\mathrm{x}$ alba as a model substrate for reduced recalcitrance. Energy Environ. Sci., 4(12), 4962-4971.

[44] Fox, J.M., Levine, S.E., Blanch, H.W., Clark, D.S., 2012. An evaluation of cellulose saccharification and fermentation with an engineered Saccharomyces cerevisiae capable of cellobiose and xylose utilization. Biotechnol. J. 7(3), 361-373.

[45] Fu, C., Mielenz, J.R., Xiao, X., Ge, Y., Hamilton, C.Y., Rodriguez, M., Chen, F., Foston, M., Ragauskas, A., Bouton, J., Dixon, R.A., Wang,
Z.Y., 2011. Genetic manipulation of lignin reduces recalcitrance and improves ethanol production from switchgrass. Proc. Natl. Acad. Sci. 108(9), 3803-3808.

[46] Funaoka, M., Matsubara, M., Seki, N., Fukatsu, S., 1995 Conversion of native lignin to a highly phenolic functional polymer and its separation from lignocellulosics. Biotechnol. Bioeng. 46(6), $545-552$.

[47] Galazka, J.M., Tian, C., Beeson, W.T., Martinez, B., Glass, N.L. Cate, J.H.D., 2010. Cellodextrin Transport in Yeast for Improved Biofuel Production. Science. 330(6000), 84-86.

[48] Grabber, J.H., Hatfield, R.D., Lu, F., Ralph, J., 2008. Coniferyl Ferulate Incorporation into Lignin Enhances the Alkaline Delignification and Enzymatic Degradation of Cell Walls Biomacromolecules. 9(9), 2510-2516.

[49] Grethlein, H.E., Converse, A.O., 1991. Common aspects of acid prehydrolysis and steam explosion for pretreating wood. Bioresour. Technol. 36(1), 77-82.

[50] Ha, S.J., Galazka, J.M., Rin Kim, S., Choi, J.H., Yang, X., Seo, J.H. Louise Glass, N., Cate, J.H.D., Jin, Y.S., 2010. Engineered Saccharomyces cerevisiae capable of simultaneous cellobiose and xylose fermentation. Proc. Natl. Acad. Sci. 108(2), 504-509.

[51] Hahn-Hagerdal, B., Berner, S., Skoog, K., 1986. Improved ethanol production from xylose with glucose isomerase and Saccharomyces cerevisiae using the respiratory inhibitor azide. Appl. Microbiol. Biotechnol. 21, 173-175.

[52] Halliwell, G., Griffin, M., 1973. The nature and mode of action of the cellulolytic component $\mathrm{C} 1$ of Trichoderma koningii on native cellulose. Biochem. J. 135(4), 587-594.

[53] Harvey, B.G., Meylemans, H.A., 2014. 1-Hexene: a renewable C6 platform for full-performance jet and diesel fuels. Green Chem. 16(2), 770-776.

[54] Hasunuma, T., Kondo, A., 2012. Development of yeast cell factories for consolidated bioprocessing of lignocellulose to bioethanol through cell surface engineering. Biotechnol. Adv. 30(6), 12071218 .

[55] He, M., Wu, B., Qin, H., Ruan, Z., Tan, F., Wang, J., Shui, Z., Dai, L., Zhu, Q., Pan, K., Tang, X., Wang, W., Hu, Q., 2014. Zymomonas mobilis: a novel platform for future biorefineries. Biotechnol. Biofuels. 7(1), 101.

[56] Holtzapple, M., Cognata, M., Shu, Y., Hendrickson, C., 1990 Inhibition of Trichoderma reesei cellulase by sugars and solvents. Biotechnol. Bioeng. 36(3), 275-287.

[57] Hong, Y., Nizami, A.S., Pour Bafrani, M., Saville, B.A., MacLean, H.L., 2013. Impact of cellulase production on environmental and financial metrics for lignocellulosic ethanol. Biofuels Bioprod. Biorefin. 7(3), 303-313.

[58] Horn, S., Vaaje-Kolstad, G., Westereng, B., Eijsink, V., 2012. Novel enzymes for the degradation of cellulose. Biotechnol. Biofuels, 5(1) 45.

[59] Hsu, D.D., Inman, D., Heath, G.A., Wolfrum, E.J., Mann, M.K. Aden, A., 2010. Life Cycle Environmental Impacts of Selected U.S. Ethanol Production and Use Pathways in 2022. Environ. Sci Technol. 44(13), 5289-5297.

[60] Hu, F., Jung, S., Ragauskas, A., 2012. Pseudo-lignin formation and its impact on enzymatic hydrolysis. Bioresour. Technol. 117, 7 12.

[61] Hu, J., Arantes, V., Pribowo, A., Gourlay, K., Saddler, J.N., 2014. Substrate factors that influence the synergistic interaction of AA9 and cellulases during the enzymatic hydrolysis of biomass. Energy Environ. Sci. 7(7), 2308-2315.

[62] Huber, G.W., Iborra, S., Corma, A., 2006. Synthesis of Transportation Fuels from Biomass: Chemistry, Catalysts, and Engineering. Chem. Rev. 106(9), 4044-4098.

[63] Jeffries, T.W., 2005. Ethanol fermentation on the move. Nat Biotechnol. 23(1), 40-41.

[64] Jeffries, T.W., Jin, Y.S., 2004. Metabolic engineering for improved fermentation of pentoses by yeasts. Appl. Microbiol. Biotechnol. 63(5), 495-509.

[65] Jin, M., Gunawan, C., Balan, V., Dale, B.E., 2012. Consolidated bioprocessing (CBP) of AFEX ${ }^{\mathrm{TM}}$-pretreated corn stover for ethanol 
production using Clostridium phytofermentans at a high solids loading. Biotechnol. Bioeng. 109(8), 1929-1936.

[66] Jordan, D.B., Bowman, M.J., Braker, J.D., Dien, B.S., Hector, R.E., Lee, C.C., Mertens, J.A., Wagschal, K., 2012. Plant cell walls to ethanol. Biochem. J. 442(2), 241-252.

[67] Karimi, K., Shafiei, M., Kumar, R., 2013. Progress in Physical and Chemical Pretreatment of Lignocellulosic Biomass, in: Gupta, V.K., Tuohy, M.G. (Eds.), Biofuel Technologies. Springer Berlin Heidelberg, pp. 53-96.

[68] Kim, S.R., Ha, S.J., Wei, N., Oh, E.J., Jin, Y.S., 2012. Simultaneous cofermentation of mixed sugars: a promising strategy for producing cellulosic ethanol. Trends Biotechnol. 30(5), 274-282.

[69] Kim, S.R., Park, Y.C., Jin, Y.S., Seo, J.H., 2013. Strain engineering of Saccharomyces cerevisiae for enhanced xylose metabolism. Biotechnol. Adv. 31(6), 851-861.

[70] Kim, T.H., Kim, J.S., Sunwoo, C., Lee, Y.Y., 2003. Pretreatment of corn stover by aqueous ammonia. Bioresour. Technol. 90(1), 39-47.

[71] Kim, Y., Ximenes, E., Mosier, N.S., Ladisch, M.R., 2011. Soluble inhibitors/deactivators of cellulase enzymes from lignocellulosic biomass. Enzyme Microb. Technol. 48(4-5), 408-415.

[72] Klein-Marcuschamer, D., Oleskowicz-Popiel, P., Simmons, B.A., Blanch, H.W., 2012. The challenge of enzyme cost in the production of lignocellulosic biofuels. Biotechnol. Bioeng. 109(4), 1083-1087.

[73] Klein-Marcuschamer, D., Simmons, B.A., Blanch, H.W., 2011. Technoeconomic analysis of a lignocellulosic ethanol biorefinery with ionic liquid pre-treatment. Biofuels Bioprod. Biorefin. 5(5), 562-569.

[74] Knauf, M., Moniruzzaman, M., 2004. Lignocellulosic biomass processing: a perspective. Int. Sugar J. 106(1263), 147-150.

[75] Konda, N., Shi, J., Singh, S., Blanch, H., Simmons, B., KleinMarcuschamer, D., 2014. Understanding cost drivers and economic potential of two variants of ionic liquid pretreatment for cellulosic biofuel production. Biotechnol. Biofuels. 7(1), 86

[76] Kristensen, J., Felby, C., Jorgensen, H., 2009. Yield-determining factors in high-solids enzymatic hydrolysis of lignocellulose. Biotechnol. Biofuels. 2(1), 11.

[77] Kuhad, R.C., Gupta, R., Khasa, Y.P., Singh, A., Zhang, Y.H.P., 2011. Bioethanol production from pentose sugars: Current status and future prospects. Renew. Sust. Energy Rev. 15(9), 4950-4962.

[78] Kumar, D., Murthy, G.S., 2011. Impact of pretreatment and downstream processing technologies on economics and energy in cellulosic ethanol production. Biotechnol. Biofuels. 4, 27.

[79] Kumar, L., Arantes, V., Chandra, R., Saddler, J., 2012. The lignin present in steam pretreated softwood binds enzymes and limits cellulose accessibility. Bioresour. Technol. 103(1), 201-208.

[80] Kumar, P., Barrett, D.M., Delwiche, M.J., Stroeve, P., 2009a. Methods for Pretreatment of Lignocellulosic Biomass for Efficient Hydrolysis and Biofuel Production. Ind. Eng. Chem. Res. 48(8), 3713-3729.

[81] Kumar, R., Hu, F., Sannigrahi, P., Jung, S., Ragauskas, A.J., Wyman, C.E., 2013. Carbohydrate derived-pseudo-lignin can retard cellulose biological conversion. Biotechnol. Bioeng. 110(3), 737-753.

[82] Kumar, R., Mago, G., Balan, V., Wyman, C.E., 2009b. Physical and chemical characterizations of corn stover and poplar solids resulting from leading pretreatment technologies. Bioresour. Technol. 100(17), 3948-3962.

[83] Kumar, R., Wyman, C.E., 2009a. Effect of additives on the digestibility of corn stover solids following pretreatment by leading technologies. Biotechnol. Bioeng. 102(6), 1544-1557.

[84] Kumar, R., Wyman, C.E., 2009b. Effect of enzyme supplementation at moderate cellulase loadings on initial glucose and xylose release from corn stover solids pretreated by leading technologies. Biotechnol. Bioeng. 102(2), 457-467.

[85] Kumar, R., Wyman, C.E., 2009c. Effects of cellulase and xylanase enzymes on the deconstruction of solids from pretreatment of poplar by leading technologies. Biotechnol. Prog. 25(2), 302-314.

[86] Kumar, R., Wyman, C.E., 2008. An improved method to directly estimate cellulase adsorption on biomass solids. Enzyme Microb. Technol. 42(5), 426-433

[87] Kumar, R., Wyman, C.E., 2010. Key features of pretreated lignocelluloses biomass solids and their impact on hydrolysis, in: Waldon, K. (Ed.), Bioalcohol production : Biochemical conversion of lignocellulosic biomass. Woodhead publishing limited, Oxford, pp 73-121.

[88] Kumar, R., Wyman, C.E., 2013. Physical and Chemical Features of Pretreated Biomass that Influence Macro-/Micro-Accessibility and Biological Processing. in: Aqueous Pretreatment of Plant Biomass for Biological and Chemical Conversion to Fuels and Chemicals. John Wiley and Sons, Ltd, pp. 281-310.

[89] Kumar, R., Wyman, C.E., 2014. Strong cellulase inhibition by Mannan polysaccharides in cellulose conversion to sugars. Biotechnol. Bioeng. 111(7), 1341-1353.

[90] Ladisch, M.R., Lin, K.W., Voloch, M., Tsao, G.T., 1983. Process considerations in the enzymatic hydrolysis of biomass. Enzyme Microb. Technol. 5(2), 82-102.

[91] Lal, R., 2005. World crop residues production and implications of its use as a biofuel. Environ. Int. 31(4), 575-584.

[92] Laluce, C., Schenberg, A., Gallardo, J., Coradello, L., PombeiroSponchiado, S., 2012. Advances and Developments in Strategies to Improve Strains of Saccharomyces cerevisiae and Processes to Obtain the Lignocellulosic Ethanol - a review. Appl. Biochem. Biotechnol. 166(8), 1908-1926.

[93] Li, C., Knierim, B., Manisseri, C., Arora, R., Scheller, H.V., Auer, M., Vogel, K.P., Simmons, B.A., Singh, S., 2010. Comparison of dilute acid and ionic liquid pretreatment of switchgrass: Biomass recalcitrance, delignification and enzymatic saccharification. Bioresour. Technol. 101(13), 4900-4906.

[94] Li, H., Pu, Y., Kumar, R., Ragauskas, A.J., Wyman, C.E., 2013. Investigation of lignin deposition on cellulose during hydrotherma pretreatment, its effect on cellulose hydrolysis, and underlying mechanisms. Biotechnol. Bioeng. 111(3), 485-492.

[95] Lin, K.W., Ladisch, M.R., Schaefer, D.M., Noller, C.H., Lechtenberg, V., Tsao, G.T., 1981. Review of effect of pretreatment on digestibility of cellulosic materials. AICHE Symp. Ser. 207(77), $102-106$

[96] Lynd, L., Greene, N., Dale, B., Laser, M., Lashof, D., Wang, M., Wyman, C., 2006. Energy returns on ethanol production. Science (New York, N.Y.), 312(5781), 1746-1748.

[97] Lynd, L.R., 1996. Overview and evaluation of fuel ethanol from cellulosic biomass :Technology, economics, the environment, and policy. Annu. Rev. Energy Env. 21, 403-465.

[98] Lynd, L.R., Cushman, J.H., Nichols, R.J., Wyman, C.E. 1991. Fuel ethanol from cellulosic biomass. Science (Washington, DC, United States), 251(4999), 1318-1323.

[99] Lynd, L.R., Grethlein, H.E., Wolkin, R.H., 1989. Fermentation of cellulosic substrates in batch and continuous culture by Clostridium thermocellum. Appl. Environ. Microbiol. 55(12), 3131-9.

[100]Lynd, L.R., Laser, M.S., Bransby, D., Dale, B.E., Davison, B. Hamilton, R., Himmel, M., Keller, M., McMillan, J.D., Sheehan, J., Wyman, C.E., 2008. How biotech can transform biofuels. Nat. Biotechnol. 26(2), 169-72

[101]Lynd, L.R., Weimer, P.J., van Zyl, W.H., Pretorius, I.S., 2002. Microbial cellulose utilization: fundamentals and biotechnology. Microbiol. Mol. Biol. Rev. 66(3), 506-77.

[102]Lynd, L.R., Wyman, C.E., Gerngross, T.U., 1999. Biocommodity Engineering. Biotechnol. Prog. 15(5), 777-793.

[103] Mandels, M., Reese, E.T., 1965. Inhibition of cellulases. Annu. Rev. Phytopathol. 3, 85-102.

[104]Millett, M.A., Baker, A.J., Satter, L.D., 1975. Pretreatments to enhance chemical, enzymatic, and microbiological attack of cellulosic materials. Biotechnol. Bioeng. Symp. (5), 193-219.

[105]Mohnen, D., 2008. Pectin structure and biosynthesis. Curr. Opin. Plant Biol. 11(3), 266-277

[106]Mosier, N., Wyman, C., Dale, B., Elander, R., Lee, Y.Y. Holtzapple, M., Ladisch, M., 2005. Features of promising technologies for pretreatment of lignocellulosic biomass. Bioresour. Technol. 96(6), 673-686.

[107]Müller, G., Várnai, A., Johansen, K.S., Eijsink, V.G.H., Horn, S.J., 2015. Harnessing the potential of LPMO-containing cellulase cocktails poses new demands on processing conditions. Biotechnol. Biofuels. 8(1), 1-9. 
[108]Narula, C.K., Li, Z., Casbeer, E.M., Geiger, R.A., Moses-Debusk, M., Keller, M., Buchanan, M.V., Davison, B.H., 2015. Heterobimetallic Zeolite, InV-ZSM-5, Enables Efficient Conversion of Biomass Derived Ethanol to Renewable Hydrocarbons. Sci. Rep. 5, 16039.

[109]Nguyen, T.Y., Cai, C.M.Z., Osman, O., Kumar, R., Wyman, C.E., 2015a. CELF Pretreatment of Corn Stover Boosts Ethanol Titers and Yields from High Solids SSF with Low Enzyme Loadings. Green Chem. DOI: 10.1039/C5GC01977J.

[110]Nguyen, T.Y., Cai, C.M., Kumar, R., Wyman, C.E., 2015b. Co-solvent Pretreatment Reduces Costly Enzyme Requirements for High Sugar and Ethanol Yields from Lignocellulosic Biomass. Chem. Sus. Chem. 8(10), 1716-1725.

[111] Olson, D.G., McBride, J.E., Joe Shaw, A., Lynd, L.R., 2012. Recent progress in consolidated bioprocessing. Curr. Opin. Biotechnol. 23(3), 396-405.

[112]Pauly, M., Gille, S., Liu, L., Mansoori, N., de Souza, A., Schultink, A., Xiong, G., 2013. Hemicellulose biosynthesis. Planta. 238(4), 627-642.

[113]Perez-Pimienta, J.A., Lopez-Ortega, M.G., Varanasi, P., Stavila, V., Cheng, G., Singh, S., Simmons, B.A., 2013. Comparison of the impact of ionic liquid pretreatment on recalcitrance of agave bagasse and switchgrass. Bioresour. Technol. 127, 18-24.

[114]Perlack, R.D., Stokes, B.J., 2011. U.S. Billion-Ton Update: Biomass Supply for a Bioenergy and Bioproducts Industry. U.S. Department of Energy, Oak Ridge National Laboratory, Oak Ridge, TN.

[115] Podkaminer, K., Kenealy, W., Herring, C., Hogsett, D., Lynd, L., 2012. Ethanol and anaerobic conditions reversibly inhibit commercial cellulase activity in thermophilic simultaneous saccharification and fermentation (tSSF). Biotechnol. Biofuels. 5(1), 43.

[116]Podkaminer, K.K., Shao, X., Hogsett, D.A., Lynd, L.R., 2011. Enzyme inactivation by ethanol and development of a kinetic model for thermophilic simultaneous saccharification and fermentation at $50{ }^{\circ} \mathrm{C}$ with Thermoanaerobacterium saccharolyticum ALK2. Biotechnol. Bioeng. 108(6), 1268-1278.

[117]Qing, Q., Yang, B., Wyman, C.E., 2010. Xylooligomers are strong inhibitors of cellulose hydrolysis by enzymes. Bioresour. Technol. 101(24), 9624-9630.

[118]Ragauskas, A.J., Beckham, G.T., Biddy, M.J., Chandra, R., Chen, F., Davis, M.F., Davison, B.H., Dixon, R.A., Gilna, P., Keller, M., Langan, P., Naskar, A.K., Saddler, J.N., Tschaplinski, T.J., Tuskan, G.A., Wyman, C.E., 2014. Lignin Valorization: Improving Lignin Processing in the Biorefinery. Science. 344(6185), 1246843.

[119]Reese, E.T., Mandels, M., 1980. Stability of the cellulase of Trichoderma reesei under use conditions. Biotechnol. Bioeng. 22(2), 323-335.

[120]Resch, M.G., Donohoe, B.S., Baker, J.O., Decker, S.R., Bayer, E.A., Beckham, G.T., Himmel, M.E., 2013. Fungal cellulases and complexed cellulosomal enzymes exhibit synergistic mechanisms in cellulose deconstruction. Energy Environ. Sci. 6(6), 1858-1867.

[121]Riittonen, T., Eränen, K., Mäki-Arvela, P., Shchukarev, A., Rautio, A.R., Kordas, K., Kumar, N., Salmi, T., Mikkola, J.P., 2015. Continuous liquid-phase valorization of bio-ethanol towards bio-butanol over metal modified alumina. Renew. Energ. 74, 369-378.

[122]Rollin, J.A., Zhu, Z., Sathitsuksanoh, N., Zhang, Y.H.P., 2011. Increasing cellulose accessibility is more important than removing lignin: A comparison of cellulose solvent-based lignocellulose fractionation and soaking in aqueous ammonia. Biotechnol. Bioeng. 108(1), 22-30.

[123]Schmer, M.R., Vogel, K.P., Mitchell, R.B., Perrin, R.K., 2008. Net energy of cellulosic ethanol from switchgrass. Proc. Natl. Acad. Sci., 105(2), 464-469.

[124]Scott, B.R., Huang, H.Z., Frickman, J., Halvorsen, R., Johansen, K.S., 2015. Catalase improves saccharification of lignocellulose by reducing lytic polysaccharide monooxygenase-associated enzyme inactivation. Biotechnol. Lett. 1-10.

[125] Seema, S., Blake, A.S., Kenneth, P.V. 2009. Visualization of biomass solubilization and cellulose regeneration during ionic liquid pretreatment of switchgrass. Biotechnol. Bioeng. 104(1), 68-75.

[126] Selig, M.J., Viamajala, S., Decker, S.R., Tucker, M.P., Himmel, M.E., Vinzant, T.B., 2007. Deposition of Lignin Droplets Produced During
Dilute Acid Pretreatment of Maize Stems Retards Enzymatic Hydrolysis of Cellulose. Biotechnol. Prog. 23(6), 1333-1339.

[127]Shao, X., Jin, M., Guseva, A., Liu, C., Balan, V., Hogsett, D., Dale, B.E., Lynd, L., 2011. Conversion for Avicel and AFEX pretreated corn stover by Clostridium thermocellum and simultaneous saccharification and fermentation: Insights into microbial conversion of pretreated cellulosic biomass. Bioresour. Technol. 102(17), 80408045 .

[128] Shaw, A.J., Podkaminer, K.K., Desai, S.G., Bardsley, J.S., Rogers, S.R., Thorne, P.G., Hogsett, D.A., Lynd, L.R., 2008. Metabolic engineering of a thermophilic bacterium to produce ethanol at high yield. Proc. Natl. Acad. Sci. 105(37), 13769-13774.

[129] Shuai, L., Questell-Santiago, Y.M., Luterbacher, J.S., 2016. A mild biomass pretreatment using [gamma]-valerolactone for concentrated sugar production. Green Chem. 18, 937-943.

[130] Singh, S., Simmons, B.A., 2013. Ionic Liquid Pretreatment: Mechanism, Performance, and Challenges, in: Aqueous Pretreatment of Plant Biomass for Biological and Chemical Conversion to Fuels and Chemicals, John Wiley and Sons, Ltd, pp. 223-238.

[131] Socha, A.M., Parthasarathi, R., Shi, J., Pattathil, S., Whyte, D., Bergeron, M., George, A., Tran, K., Stavila, V., Venkatachalam, S., Hahn, M.G., Simmons, B.A., Singh, S., 2014. Efficient biomass pretreatment using ionic liquids derived from lignin and hemicellulose. Proc. Natl. Acad. Sci. 111(35), E3587-E3595.

[132] Somerville, C., Youngs, H., Taylor, C., Davis, S.C., Long, S.P., 2010. Feedstocks for Lignocellulosic Biofuels. Science. 329(5993), 790-792

[133] Spindler, D.D., Wyman, C.E., Grohmann, K., 1989. Evaluation of thermotolerant yeasts in controlled simultaneous saccharifications and fermentations of cellulose to ethanol. Biotechnol. Bioeng. 34(2), 189-195

[134] Sreekumar, S., Baer, Z.C., Gross, E., Padmanaban, S., Goulas, K., Gunbas, G., Alayoglu, S., Blanch, H.W., Clark, D.S., Toste, F.D., 2014. Chemocatalytic Upgrading of Tailored Fermentation Products Toward Biodiesel. Chem. Sus. Chem. 7(9), 2445-2448.

[135] Stephen, J.D., Mabee, W.E., Saddler, J.N., 2012. Will secondgeneration ethanol be able to compete with first-generation ethanol? Opportunities for cost reduction. Biofuels Bioprod. Biorefin. 6(2), $159-176$

[136] Sticklen, M.B., 2008. Plant genetic engineering for biofuel production: towards affordable cellulosic ethanol. Nat. Rev. Genet. 9(6), 433-443.

[137]Studer, M.H., DeMartini, J.D., Davis, M.F., Sykes, R.W., Davison, B., Keller, M., Tuskan, G.A., Wyman, C.E., 2011. Lignin content in natural Populus variants affects sugar release. Proc. Natl. Acad. Sci. 108(15), 6300-6305.

[138]Sun, J., Wang, Y., 2014. Recent Advances in Catalytic Conversion of Ethanol to Chemicals. ACS Catal. 4(4), 1078-1090.

[139]Swatloski, R.P., Spear, S.K., Holbrey, J.D., Rogers, R.D., 2002 Dissolution of Cellose with Ionic Liquids. J. Am. Chem. Soc. 124(18), 4974-4975

[140] Trajano, H.L., Wyman, C.E., 2013. Fundamentals of Biomass Pretreatment at Low pH. in: Aqueous Pretreatment of Plant Biomass for Biological and Chemical Conversion to Fuels and Chemicals, John Wiley and Sons, Ltd, pp. 103-128.

[141]Urbanowicz, B.R., Pena, M.J., Ratnaparkhe, S., Avci, U., Backe, J., Steet, H.F., Foston, M., Li, H., O'Neill, M.A., Ragauskas, A.J., Darvill, A.G., Wyman, C., Gilbert, H.J., York, W.S., 2012. 4-Omethylation of glucuronic acid in Arabidopsis glucuronoxylan is catalyzed by a domain of unknown function family 579 protein Proc. Natl. Acad. Sci. 109(35), 14253-14258.

[142] Vaaje-Kolstad, G., Westereng, B., Horn, S.J., Liu, Z., Zhai, H., Sorlie, M., Eijsink, V.G.H., 2010. An Oxidative Enzyme Boosting the Enzymatic Conversion of Recalcitrant Polysaccharides. Science. $330(6001), 219-222$

[143] Viljoen, J.A., Fred, E.B., Peterson, W.H., 1926. The fermentation of cellulose by thermophilic bacteria. J. Agric. Sci. 16(01), 1-17. 
[144] Vincent, C., Nagwani, S., Holtzapple, M., Mark T., 1998. Lime pretreatment of crop residues bagasse and wheat straw. Appl. Biochem. Biotechnol. 74(3), 135-159.

[145] Wagner, A., Tobimatsu, Y., Phillips, L., Flint, H., Geddes, B., Lu, F., Ralph, J., 2015. Syringyl lignin production in conifers: Proof of concept in a Pine tracheary element system. Proc. Natl. Acad. Sci. 112(19), 6218-6223

[146]Wang, X., Yomano, L.P., Lee, J.Y., York, S.W., Zheng, H., Mullinnix, M.T., Shanmugam, K.T., Ingram, L.O., 2013. Engineering furfural tolerance in Escherichia coli improves the fermentation of lignocellulosic sugars into renewable chemicals. Proc. Natl. Acad. Sci. 110(10), 4021-4026.

[147] Whitcraft, D.R., Verykios, X.E., Mutharasan, R., 1983. Recovery of ethanol from fermentation broths by catalytic conversion to gasoline. Ind. Eng. Chem. Process Des. Dev. 22(3), 452-457.

[148] Wilkerson, C.G., Mansfield, S.D., Lu, F., Withers, S., Park, J.Y., Karlen, S.D., Gonzales-Vigil, E., Padmakshan, D., Unda, F., Rencoret, J., Ralph, J., 2014. Monolignol Ferulate Transferase Introduces Chemically Labile Linkages into the Lignin Backbone. Science. 344(6179), 90-93.

[149]Wu, M., Yan, Z.Y., Zhang, X.M., Xu, F., Sun, R.C., 2016. Integration of mild acid hydrolysis in $\gamma$-valerolactone/water system for enhancement of enzymatic saccharification from cotton stalk. Bioresour. Technol. 200, 23-28.

[150] Wyman, C.E., 2007. What is (and is not) vital to advancing cellulosic ethanol. Trends Biotechnol. 25(4), 153-157.

[151]Wyman, C.E., Dale, B.E., Balan, V., Elander, R.T., Holtzapple, M.T., Ramirez, R.S., Ladisch, M.R., Mosier, N.S., Lee, Y.Y., Gupta, R., Thomas, S.R., Hames, B.R., Warner, R., Kumar, R., 2013. Comparative Performance of Leading Pretreatment Technologies for Biological Conversion of Corn Stover, Poplar Wood, and Switchgrass to Sugars, in: Aqueous Pretreatment of Plant Biomass for Biological and Chemical Conversion to Fuels and Chemicals, John Wiley and Sons, Ltd, pp. 239259.

[152] Wyman, C.E., Ragauskas, A.J., 2015. Lignin Bioproducts to Enable Biofuels. Biofuels Bioprod. Biorefin. 9(5), 447-449.
[153]Ximenes, E., Kim, Y., Mosier, N., Dien, B., Ladisch, M., 2010. Inhibition of cellulases by phenols. Enzyme Microb. Technol. 46 $170-176$.

[154] Yamada, R., Hasunuma, T., Kondo, A., 2013. Endowing noncellulolytic microorganisms with cellulolytic activity aiming for consolidated bioprocessing. Biotechnol. Adv. 31(6), 754-763.

[155] Yang, B., Wyman, C.E., 2006. BSA treatment to enhance enzymatic hydrolysis of cellulose in lignin containing substrates. Biotechnol. Bioeng. 94(4), 611-617.

[156] Yang, B., Wyman, C.E., 2009. Dilute acid and autohydrolysis pretreatment. Methods Mol. Biol. 581, 103-114.

[157] Yang, B., Wyman, C.E., 2008. Pretreatment: the key to unlocking low-cost cellulosic ethanol. Biofuels Bioprod. Biorefin. 2(1), 26-40.

[158] Yang, S.J., Kataeva, I., Hamilton-Brehm, S.D., Engle, N.L. Tschaplinski, T.J., Doeppke, C., Davis, M., Westpheling, J., Adams, M.W.W., 2009. Efficient Degradation of Lignocellulosic Plant Biomass, without Pretreatment, by the Thermophilic Anaerobe "Anaerocellum thermophilum" DSM 6725. Appl. Environ. Microbiol. 75(14), 4762-4769

[159]Yee, K., Rodriguez Jr, M., Thompson, O., Fu, C., Wang, Z.Y. Davison, B., Mielenz, J., 2014. Consolidated bioprocessing of transgenic switchgrass by an engineered and evolved Clostridium thermocellum strain. Biotechnol. Biofuels. 7(1), 75

[160] Yoon, H., Wu, Z., Lee, Y., 1995. Ammonia-recycled percolation process for pretreatment of biomass feedstock. Appl. Biochem. Biotechnol. 51(1), 5-19.

[161]Zhang, Y.H.P., Ding, S.Y., Mielenz, J.R., Cui, J.B., Elander, R.T. Laser, M., Himmel, M.E., McMillan, J.R., Lynd, L.R., 2007. Fractionating recalcitrant lignocellulose at modest reaction conditions. Biotechnol. Bioeng. 97(2), 214-223.

[162]Zhu, J.Y., Pan, X.J., 2010. Woody biomass pretreatment for cellulosic ethanol production: Technology and energy consumption evaluation. Bioresour. Technol. 101(13), 4992-5002.

[163]Zhu, J.Y., Pan, X.J., Wang, G.S., Gleisner, R., 2009. Sulfite pretreatment (SPORL) for robust enzymatic saccharification of spruce and red pine. Bioresour. Technol. 100(8), 2411-2418. 